\title{
Documentation of pest management practices among banana growers in major banana growing districts of Tamil Nadu
}

\author{
NIKITA S. AWASTHI* AND S. SRIDHARAN
}

Department of Agricultural Entomology, Tamil Nadu Agricultural University, COIMBATORE (T.N.) INDIA

\section{ARITCLE INFO \\ Received : 11.01 .2017 \\ Revised : 02.03 .2017 \\ Accepted : 08.03.2017}

\section{KEY WORDS :}

Insecticide usage pattern, Pseudostem injection, Pseudostem borer

*Corresponding author:

Email:nikita.agri19@gmail.com

\begin{abstract}
A survey was conducted during the year 2014-2015 in major banana growing district of Tamil Nadu to study the pest management practices against major pests of banana. The studies revealed low responses on knowledge about eco-friendly pest management practices except following the clean cultivation practices $(61.25 \%)$ and use of plant products $(54.17 \%)$. Awareness about the recommended pesticides for banana was low ( $17.50 \%$ respondents) and many of the banana growers (42.5\%) use monocrotophos against banana pests. Around 46.25 per cent of farmers get their plant protection advice from pesticide dealers. Interventions for eco-friendly pest management with the rational and sustainable use of pesticides in banana is necessary among the banana growers.
\end{abstract}

How to view point the article : Awasthi, Nikita S. and Sridharan, S. (2017). Documentation of pest management practices among banana growers in major banana growing districts of Tamil Nadu. Internat. J. Plant Protec., 10(1) : 63-68, DOI : 10.15740/HAS/IJPP/10.1/63-68. 